\title{
norden
}

Nordisk råd

Ved Stranden 18

DK-1061 København K

www.norden.org

NORDISKE ARBEJDSPAPIRER

NOR DISKE ARBEIDSPAPIRER

\section{EUs svoveldirektiv og sjøfarten i Østersjøen}

Implementeringen av EUs svoveldirektiv, konsekvenser og muligheter i Norden

Nordisk råds arbeidsgruppe vedrørende EUs svoveldirektiv

NA2013:922

http://dx.doi.org/10.6027/NA2013-922 


\section{EUs svoveldirektiv og sjøfarten i Østersjøen}

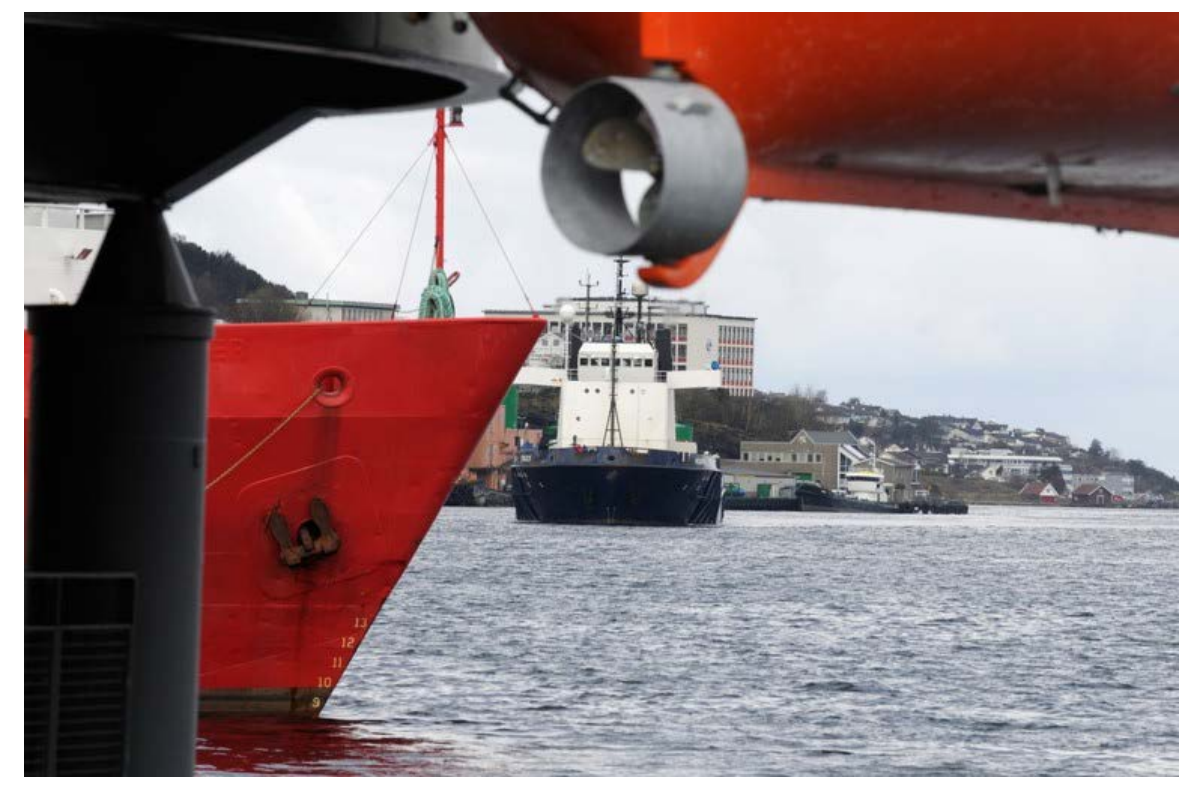

Fotograf: Johannes Janson - norden.org

Implementeringen av EUs svoveldirektiv, konsekvenser og muligheter i Norden 


\section{Indhold}

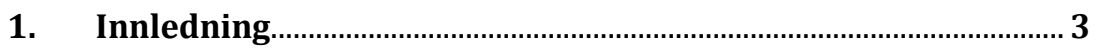

2. Hovedkonklusjoner...................................................................... 4

3. Mulige tekniske og andre løsninger.............................................. 5

4. Forventet effekt av svoveldirektivet............................................. 9

5. Offentligt tiltak for å lette tilpasning til svoveldirektivet....... 11

5.1 Den Europeiske Union ................................................................. 11

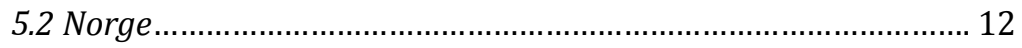

5.3 Finland ............................................................................ 13

5.4 Sverige .................................................................................. 13

5.5 Danmark ............................................................................. 14

5.6 Øvrige Østersjøland ............................................................... 14

6. Konklusjoner og anbefalinger om felles nordiske tiltak.......... 15

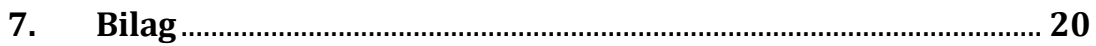

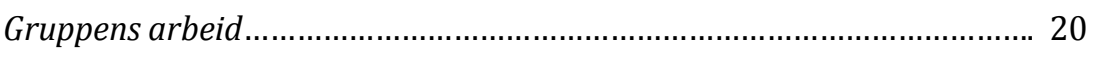

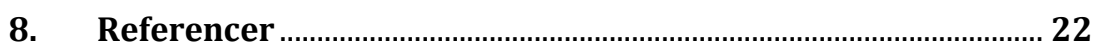




\section{Innledning}

Fra 1. januar 2015 skjerpes kravene om svovelinnholdet i marinbrensel i Østersjøen, Nordsjøen og Den engelske kanal, samt kystområder i NordAmerika ${ }^{1}$. Innholdet senkes fra nåværende nivå på $1 \%$ til $0,1 \%$. Utenfor disse områder skjerpes kravene først fra 2020, og da kun til 0,5 \% svovelinnhold ${ }^{2}$. Som alternativ til lavere svovelinnhold kan skip ha rensningsanlegg som gir samme standard.

Globalt er utslipp til luften fra skipstrafikken regulert ved MARPOLkonvensjonen, som administreres av Den internasjonale maritimorganisasjon (IMO). I overensstemmelse med MARPOL har EU i november 2012 vedtatt et direktiv om svovelutslipp 3 .

Renseanlegg, nye teknologier eller alternativ brensel ventes både å forbedre miljø og helbred i Østersjøen. Baksiden er merkostnader ved sjøtransport. De nye krav er derfor en utfordring for landene rundt Østersjøen. Industriene i disse landene er utsatt for konkurranse på det globale markedet, og transportkostnader har konsekvenser for konkurranseposisjonen når ikke andre områder, som de konkurrer med, er underlagt de samme strenge krav.

Fire nordiske land vil bli påvirket av de nye kravene, nemlig Danmark, Finland, Sverige og Norge. På fellesmøtet i Nordisk råds Næringsutvalg og Miljø- og naturressursutvalg i Reykjavik i januar 2013 ble det besluttet å opprette en arbeidsgruppe for å se på de nye utfordringene. Gruppen besto av følgende medlemmer:

Oskar Grimstad (Norge) Miljø- og naturressursutvalget Anders Eriksson (Åland), Miljø- og naturressursutvalget Thomas Danielsen (Danmark), Miljø- og naturressursutvalget Billy Gustafsson (Sverige), Næringsutvalget Eero Suutari (Finland), Næringsutvalget

På gruppens første møte i Stockholm den 10. april ble Oskar Grimstad valgt som leder av arbeidsgruppen og Anders Eriksson som nestleder. Seniorrådgiverne Johan Lindblad og Tryggvi Felixson i Nordisk råds sekretariat har arbeidet med gruppen.

\footnotetext{
${ }^{1}$ På fagspråk kalles området SECA, som er forkortelse for Sulphur Emission Control Area)

2 Beslutning er dog betinget at det skal tas stilling til et mulig alternativt tidspunkt i 2018.

3 Directive 2012/33/EU of the European Parliament and of the Council of 21 November 2012 amending Council Directive 1999/32/EC as regards the sulphur content of marine fuels
} 
Arbeidsgruppen fikk i oppdrag å vurdere mulige felles nordiske tiltak for å lette implementering av svoveldirektivet for sjøfarten i Østersjøen, Kattegat og Nordsjøen, og utarbeide forslag til innspill fra Nordisk råds side herom. Videre, å skape klarhet om mulige testperioder for nye teknologier eller andre former for overgangs-ordninger ved innføringen av svoveldirektivet $\mathrm{i}$ 2015. Gruppen konstaterte, at som direktivet er formet vil det ikke være mulig med testperioder etter 1. januar 2015. Gruppen anså det derfor ikke hensiktsmessig å arbeide videre med denne delen av oppdraget, og rapporterte dette til de to respektive utvalg på sommermøtet 2013.

\section{Hovedkonklusjoner}

Nye krav om utslipp av svovel vil ha gunstige miljø- og helbredseffekter. De er i linje med det grunnleggende miljøpolitiske prinsipp, at forurenseren skal betale for sin miljøpåvirkning eller tiltak for å begrense den. Heldigvis finnes det nye teknologier og alternative brensel som gjør det mulig for sjøfarten å tilpasse seg. De nye krav ventes også å fremme teknologisk utvikling og skape nye muligheter for nordiske industrier, som satser på renere teknologier.

Anvendelsen av nye renere teknologier og alternativ brensel innebærer $ø$ kte driftskostnader, både på kort og mellomlangt sikt. For områdets konkurranseevne er det en stor utfordring, at det vil gjelde lempeligere regler om svovelutslipp for den meste av verden i forhold til Østersjøen, Kattegat og Nordsjøen. Videre er byrden ved å implementere de nye regler om svovelutslipp ikke likt fordelt innenfor området. Noen områder og industrier i Finland og Sverige, ventes uten hjelpende tiltak, å bli hardt belastet. Videre, er det sannsynlig at transport av varer overføres fra sjø til vei, som fra et miljøperspektiv er en uheldig utvikling.

For å motvirke de negative konsekvensene av de nye regler anbefaler arbeidsgruppen

at de nordiske lands regjeringer

- implementer tiltak for å opprettholde og styrke sjøfartens konkurransekraft

- samarbeider om å utvikle felles reguleringer for bruk av LNG i Norden og internasjonalt

- utarbeider nasjonale planer for opprettelse av LNG terminaler i nordiske havner

- $\quad$ arbeider for at samme regler gjelder for flammepunkt for marin diesel som for alminnelig diesel

- innenfor EU, IMO og andre relevante internasjonale fora, arbeider for at samme regler som gjelder for utslipp av svovel i Østersjøen, Kattegat og Nordsjøen, samt Nord-Amerikas kyst, også tidligst mulig gjelder for andre havområder 
- kartlegger den eksisterende skipsflåte som betjener landene, for å belyse omfanget av den omstillingen som implementeringen av svoveldirektivet forutsetter

- skape økonomiske insitament for bruk av renere teknologier i sjøfarten, som bygger på erfaringene med det norske NOx-fondet

at Danmarks, Finlands og Sveriges regjering

- inkluderer finansiering av infrastruktur for sjøtransport, inklusive LNG-terminaler, i partnerskapsavtaler om midler fra EUs strukturfond i perioden 2014 til 2020

at regjeringen i Norge, Sverige og Finland

- samordner og prioriterer gjennomføringen av planer om å styrke og utvide jernbanekapasiteten i de nordlige områder, samt forbindelse til havner i Norden utenfor SECA-området, som til eksempel Narvik og Trondheim

at regjeringene i Sverige og Finland

- undersøker konsekvensene av implementeringen av svoveldirektivet på særlig utsatte sektorer i avgrensede geografiske områder, samt om det i en overgangsperiode er mulig å innføre spesielle regionalbaserte tiltak for å unngå den negative innvirkning implementeringen av svoveldirektivet vil ha på lokal og regional økonomi

\section{Mulige tekniske og andre løsninger}

Gruppen har under processens gång diskuterat olika tänkbara tekniska, ekonomiska och infrastrukturella metoder för att försöka mildra de negativa effekterna av svaveldirektivets införande, vad gäller näringslivets konkurrensförutsättningar, utan att för den saks skull bidra till att den miljömässiga belastningen för Östersjön eller länderna runt Östersjön förvärras.

Inom branschen och i stort, kan man se olika tänkbara tekniska lösningar för att få ner utsläppen av svavel från fartyg. Här nedan beskrivs flertalet av dessa.

\section{Scrubbers}

Scrubbers är en relativt enkel och billig lösning som skulle kunna användas på äldre skepp. Scrubbertekniken går ut på att rena utsläppet vid förbränningen av traditionell tjockolja från skeppet i fråga. Restprodukten kan sedan deponeras i hamn, eller dumpas i havet ${ }^{4}$. Den sistnämnda lösningen är

${ }^{4}$ Muligheten til å at deponere restprodukter i havet ventes å bli underlagt regulering i fremtiden. 
miljömässigt olämplig, medan deponi i hamn vore möjlig om det hade funnits en infrastruktur för att ta emot och slutbehandla/transportera bort detta avfall från hamnarna. Detta saknas idag. Det främsta problemet med scrubber-tekniken är dock sannolikt att scrubbers tar mycket plats ombord på skeppen, på bekostnad av viktigt lastutrymme för varor. Också stabiliten på fartygen påverkast negativt. Även om scrubbertekniken nämns som en möjlig teknisk lösning, så förefaller det ej vara den metod som man inom näringen tror mest på på sikt.

\section{Flytande naturgas (LNG)}

Flytande naturgas är en bränsleform som i sig är lågsvavlig. Tack vare nedkylingen av gasen så är den inte heller särskilt skrymmande eller brandfarlig. Inom branschen omtalas LNG som sjöfartens framtida bränsle par preference, men det saknas ännu en fungerande infrastruktur för att få fram LNG till fartygen och i hamnarna. LNG är också ett bränsle som det är svårt att konvertera äldre skepp till att använda, men det finns en trend att nya skepp byggs för att drivas med LNG. Nästan $20 \%$ av fartygen är 30-40 år gamla och kan komma att ersättas fram till 2015-2020. Därmed finns en potential att nybyggda fartyg blir utrustade för LNG-drift.

Viking Line har satsat på LNG för sitt nya skepp Viking Grace, som ska trafikerar sträckan Stockholm-Åbo. Bunkring av LNG kan ske från annan båt, till havs eller i hamn, via ledning, eller direkt från lastbil. Enligt Viking Line har de genom att övergå till LNG förbrukat $70 \%$ mindre bränsle jämfört med tidigare ${ }^{5}$. Det saknas dock ett regelverk för bunkring av LNG, något som man dock kikar på på europeisk nivå. Inte heller finns det något tydligt regelverk i förhållande till bunkring av LNG på skepp med passagerare ombord.

Fartyg som är byggda för att drivas med LNG, kan också i framtiden drivas med biogas. LNG skapar inte heller något avfall, och utsläppen av klimatgaser reduceras med 15 \%. Även själva hanteringen ombord på fartygen blir renare och enklare jämfört med när fartyg drivs med tjockolja. Dock saknas det utbildningar för hantering av LNG, och det saknas regelverk kring hantering av LNG på land.

Idag finns LNG bara i stora hamnar i Norden, då det är för dyrt att bygga ut i mindre hamnar. Etableringen av mindre LNG-terminaler undersöks dock. Enligt branschens bedömning klarar sjöfartsaktörerna inte själva att driva fram en övergång till LNG i större skala. Även industrin måste börja gå över till LNG, som alternativ till kol och kärnkraft m.m., för att det ska bli mer

\footnotetext{
${ }^{5}$ Norges Rederiforbund, i uttalelse framlagt på arbeid sgruppen møte den 24. juni, hevder at forskning viser at flytende naturgass som drifstoff på skip vil eliminere partikkel- og svovelutslipp, minske $\mathrm{CO}_{2}$ utslipp med 15-20 prosent og redusere NOx-utslippene med 90 prosent.
} 
tillgängligt i samhället. I vissa länder (Sverige särskilt) finns det samtidigt en politisk skepsis mot att storsatsa på LNG som bränsle, då man inte önskar investera in sig i ett nytt fossilt beroende överlag. På kartbilden nedan kan man se var det idag existerar eller planeras LNG-terminaler och bunkringsmöjligheter.

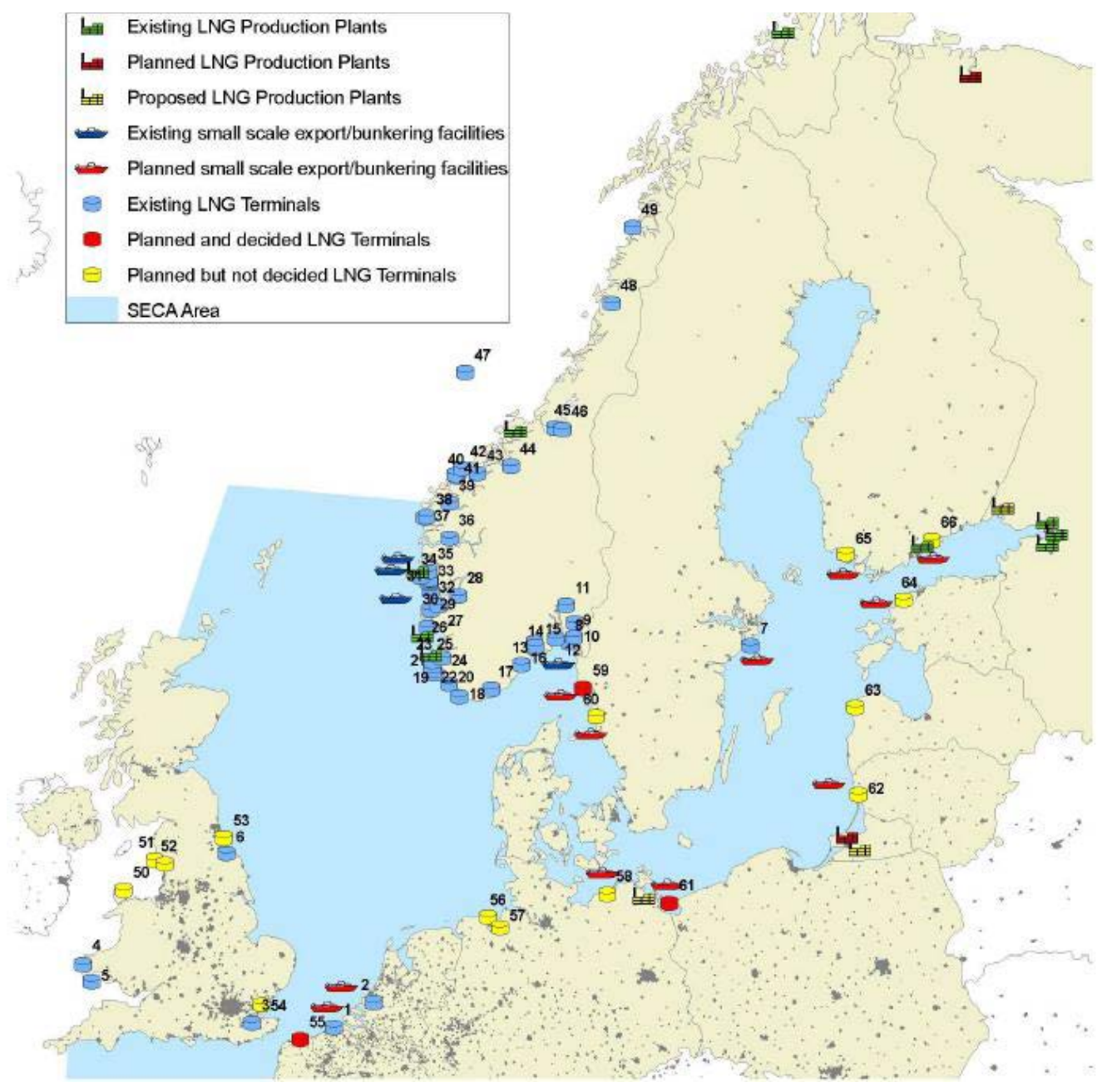

\section{Marint Diesel}

Som alternativ till dagens primära bränsle inom sjöfarten, tjockolja, kunde man i ökande grad övergå till marint diesel. Marin diesel är dock betydligt dyrare än tjockolja, och dessutom är risken överhängande att priset på marint diesel ökar kraftigt i framtiden. För att reducera pressen på priset på marint diesel, skulle man kunna sänka kravet på flampunkten för marint diesel, från dagens 60 grader $\mathrm{C}$ till 52 grader $\mathrm{C}$, så som den är för vanlig vägdiesel. En övergång från särskild marin diesel, till vanlig diesel inom sjöfarten, skulle dessutom utjämna konkurrensförhållandena mellan vägtransporter och sjötransporter. I takt med att alltmer skifferolja utvinns, och bilparken övergår till el, kommer också priset och efterfrågan på diesel att 
minska, till förmån för sjöfarten. Långsiktigt är dock dieselförbränning inte det optimala drivmedlet ur miljösynpunkt.

\section{Metanol och Biobränsle}

Metanol är också ett tänkbart bränsle i framtiden, men brandrisken med metanol är större då flampunkten är endast 12 grader C. Vad gäller biobränsle så är det sannolikt att detta kan bli ett framtida bränsle, då det kan användas i samma förbränningssystem som LNG. Utbudet av biobränsle på marknaden är än så länge dock alltför litet.

Förutom byte av bränslen eller andra tekniska omställningar, finns det också möjlighet att motverka en försämrad konkurrens genom att satsa på andra former av transportmedel/infrastruktur. Alla dessa alternativ är dock inte önskvärda ur miljösynpunkt.

\section{Ökade transporter på räls}

En tänkbar lösning på såväl miljö- som konkurrensförhållandena, vore att överföra en större del av godsfrakten från sjöfart till räls. Exempelvis i östvästlig riktning, där varken Narviks hamn eller Trondheims hamn och farvattnen utanför dessa, omfattas av de SECA-restriktioner som sjöfarten i Östersjön, Kattegatt, Skagerrak och södra Nordsjön omfattas av. Det som gör att detta på kort sikt inte är möjligt är dock att det råder kapacitetsbrist på flertalet av de aktuella sträckorna och att investeringskostnaderna och projekteringstiderna är alltför långa för att detta ska kunna lösa näringslivets konkurrenssituation på kort sikt.

\section{Ökade vägtransporter}

En tänkbar konsekvens av införandet av Svaveldirektivet, är att fler transporter övergår från sjö till land. Även om detta skulle kunna mildra de negativa konkurrensförhållandena, så finns det miljömässiga skäl att motsätta sig en sådan utveckling. Dessutom krävs det ofantliga mängder lastbilar för att transportera samma mängd gods som man kan få ombord på ett genomsnittligt fartyg. Vill man politiskt motverka att en ökande andel transporter övergår från sjö till land, kunde olika avgifter, såsom hamnavgifter för lastbilar och vägavgifter användas för att jämna ut kostnadsbilden mellan väg och sjö. Detta påverkar dock inte den nordiska industrins konkurrenssituation i positiv riktning.

\section{Gynnande av rena fartyg}

T.ex. Sverige använder farledsavgifter för att premiera övergången till renare bränslen och tekniker. Detta kan användas som incitament för att befrämja snabbare omställning, men påverkar på sikt inte konkurrenssituationen inom SECA-området då samtliga fartyg är bundna av samma regelverk kring utsläpp. 


\section{Forventet effekt av svoveldirektivet}

Ifølge HELCOM bidrar den voksende skipstrafikk i Østersjøen betydelig til både luft- og vannforurensning i Østersjøområdet. Utslipp av svoveldioksid $\left(\mathrm{SO}_{2}\right)$ stammer fra brensel som inneholder svovel og partikler, som skader både miljø og menneskers helbred ${ }^{6}$. Skipstrafikken har også en stor andel i utslipp av NOx og bidrar derfor til eutrofiering av Østersjøen ifølge HELCOM. Skipstrafikken har også andre uheldige følger som utslipp av $\mathrm{CO}_{2}$, ozon-nedbrytende stoffer og VOCs (volatile organic compounds). Alle disse negative påvirkninger vil bli kraftig redusert ved implementeringen av de strengere regler i 2015.

På kort sikt kan transportsektorene ikke omstille seg til nye teknologier. Derfor ventes størstedelen av skipene i Østersjøen å skifte fra tungolje til marin dieselolje med lavt innehold av svovel i 2015. Det er tale om dyrere brensel i forhold til det som brukes i dag. De nye regler vil medføre økt etterspørsel etter dieselolje. Prisen på dieselolje med lavt svovelinnhold ventes derfor å stige ${ }^{7}$. For marindiesel gjelder krav om flammepunkt ved 60 graders varme. For alminnelig diesel er det krav om 52 grader $\mathrm{C}$ flammepunkt, noe som gjør det ulovlig å bruke det som substitutt for marindiesel. Det bidrar til å presse prisen på marindiesel oppad 8 .

Sjøtrafikken vil på kort sikt i en viss grad kunne tilpasse seg høyere priser ved å redusere bruk av brensel. Det kan den gjøre bl.a. ved å redusere hastighet. På lengre sikt vil nye teknologier og alternative brensel bli den vesentlige tilpasning. Selv om noen av merkostnaden absorberes med økt effektivitet og nye teknologier, vil skipstrafikkens relative konkurransesituasjon bli forverret. Noe av transporten vil bli flyttet til jernbanetransport og noe til veitransport, med negative miljøkonsekvenser som følge. Kapasiteten på jernbaner er begrenset, men kan utbygges over tid, både ved å styrke eksisterende baner og bygge nye ${ }^{9}$.

I en rapport fra EU kommisjonen i $2010^{10}$ konstateres at det finnes teknologiske løsninger, som supplert med andre foranstaltninger, kan nedbringe både de stigende $\mathrm{CO}_{2}$-udledninger og $\mathrm{SO}_{2}$-udledninger fra skipsfarten. Ana-

\footnotetext{
${ }^{6} \mathrm{http}: / /$ www.helcom.fi/shipping/emissions/en_GB/emisions/

7 I rapporten Konsekvenser av skärpta krav för svavelhalten i marint bränsel - delredovisning (Trafik analyse, rapport 2013:7) vurdres at prisforskjellen mellom det brensel som brukes i dag og brennsel med lavt innhold av svovel vil være 50 til $75 \%$.

8 Saken var til behandling på møte i IMOs utvalg for maritim sikkerhet (92. møte) med utgangspunkt i et forslag fra USA. Ifølge den dokumentasjon som USA presenterte på møtet finnes det ikke saklig grunnlag for at flammepunktet på marindiesel og alminnelig diesel er forskjellig.

${ }^{9}$ Nordisk råd vedtok i 2012 en rekommandasjon om å styrke Ofotbanen, og utvidet banen slik at den også åpner for transport fra Finland til Narvik.

${ }_{10}$ Regulating Air Emissions from Ships
} 
lyser indikerer at det generelt er samfunnsmessig lønnsomt å redusere utslipp for å oppnå en gunstig miljøeffekt og bedre helbred. Det er dog tvilsomt at kostnader og nytte er like fordelt. En foreløpig svensk vurdering indikerer at de totale transport-kostnader vil øke med 2,4 til 4,6 milliarder SEK. Det konkluderes at det er usikkert at miljøgevinsten i Sverige står i proporsjon til disse kostnader, i det minste hvis man ser bort fra de sydligste delene av Sverige ${ }^{11}$.

Den positive effekt av de strengere regler er ikke alene knyttet til bedre miljø og helbred. Den marinbaserte industri i Norden øyner nye muligheter med nye teknologiske løsninger. Området kan bli et foregangsområde hvor nye teknologier vil bli testet og som på sikt vil sprede seg til resten av verden. Det ville skape nye muligheter og arbeidsplasser. For å se de fulle konsekvenser av nye regler er det nødvendig både å se på geografi og produksjonssektor. Noen geografiske områder og noen sektorer er meget følsomme overfor transportkostnader. Det gjelder ikke minst metall- og papirindustriene i de nordlige områder av Sverige och Finland.

\section{MARPOL Annex VI}
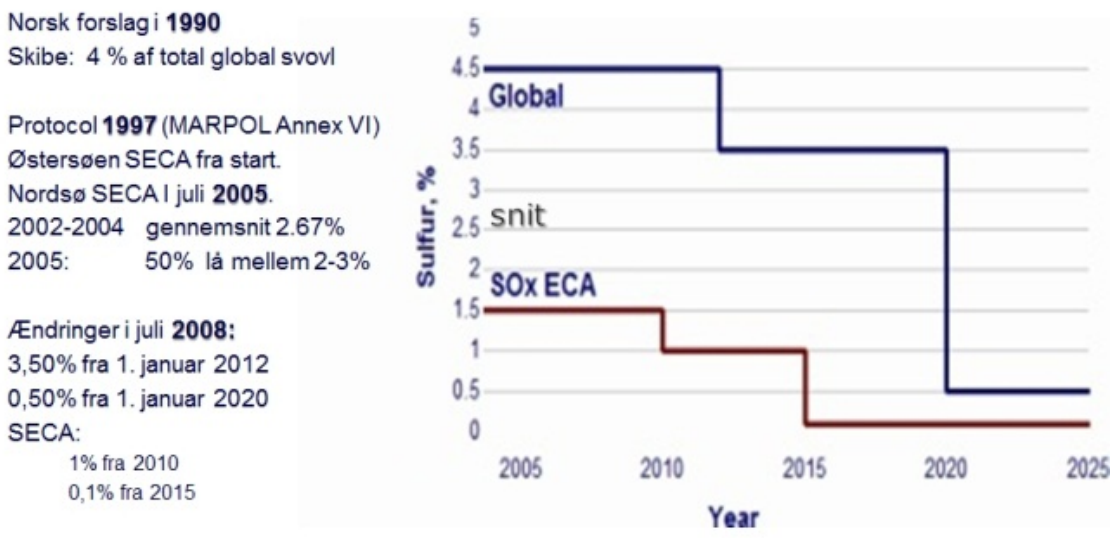

Bildet på föregående sida er fra Danske Maritime ${ }^{12}$ og viser oppstrammingen av reglene for utslipp av svovel fra sjøfart. Det fremgår at nåværende nivå er 1 \% i SECA området (Østersjøen, Kattegat og Nordsjøen og den amerikanske kyst) men 3,5 \% globalt. Gjennomsnittene for svovelutslipp innenfor sjøfarten som helhet er 2,5\%, som er lavere enn de globale regler påkrever. I SECA området settes nivået ned til 0,1 \% i 2015, mens de globale regler strammes til 0,5\% i 2020.

\footnotetext{
${ }^{11}$ Konsekvenser av skärpta krav för svavelhalten I marint bränsel - delredovisning (Trafik analyse, rapport 2013:7)

12 Fra en presentasjon på gruppens møte i København den 28. august.
} 


\section{Offentligt tiltak for å lette tilpasning til svoveldirektivet}

\subsection{Den Europeiske Union}

\section{Ten-T}

EU-har ingen støtteordning som er øremerket til innføringen av svoveldirektivet. Men innenfor EUs transportstrategi, TEN, er det en finansieringsordning som medlemslandene kan trekke på. I Perioden 2007-2013 var 8 milliarder Euro bevilget til dette formål, og nylig har Kommisjonen, Parlamentet og Rådet blitt enig om en ny program-periode fram til 202013. Det har vært årlige ansøkningsrunder, den siste ble avsluttet i februar 2013. Noen av midlene er bevilget til sjøfarten, og det har flere land rundt Østersjøen gjort bruk av. Et eksempel er bevilgning til et utredningsprosjekt om harmonisering av LNG infrastruktur i Østersjøen, som involverer havnene i Århus, Helsingborg, Helsingfors, Malmø-København, Tallin, Åbo og Stockholm ${ }^{14}$. Prosjektet beskrives som «pre-investment study» er til 3,4 MEuro, hvorav halvparten kommer fra TEN-T. I prosjektoversikten finnes det flere prosjekter som vedrører sjøfarten i Østersjøen.

\section{Strukturfondene}

EUs fond for Regional utvikling (ERDF) ${ }^{15}$ kan i prinsippet også anvendes til å finansiere infrastruktur i Danmark, Finland og Sverige. Det foregår for tiden utvikling av nasjonale programmer og partnerskapsavtaler mellom medlemslandene og EU for EUs struktur-fond i perioden 2014 til 2020. Infrastrukturinvesteringer for å redusere sjøfartens miljøpåvirkning er støtteberettiget og også tiltak for å øke samarbeid mellom byer og regioner om sjøtransport. En forutsetning er at prosjektene inngår i de nasjonale planer samt partnerskapsavtalen med EU-Kommisjonen.

\footnotetext{
13 Beskrivelse fra en pressemelding: The new core TEN-T network will be supported by a comprehensive network of routes, feeding into the core network at regional and national level. This will largely be financed by Member States, with some EU transport and regional funding possibilities, including with new innovative financing instruments. The aim is to ensure that progressively, and by 2050 , the great majority of Europe's citizens and businesses will be no more than 30 minutes' travel time from the comprehensive network. 14 Kilde: http://tentea.ec.europa.eu/en/home/

15 Kilde: http://ec.europa.eu/regional policy/thefunds/regional/index en.cfm

The ERDF aims to strengthen economic and social cohesion in the European Union by correcting imbalances between its regions. In short, the ERDF finances: direct aid to investments in companies (in particular SMEs) to create sustainable jobs; infrastructures linked notably to research and innovation, telecommunications, environment, energy and transport; financial instruments (capital risk funds, local development funds, etc.) to support regional and local development and to foster cooperation between towns and regions; technical assistance measures.
} 


\section{Marco Polo og EIB}

I et arbeidsdokument fra EU Kommisjonen ${ }^{16}$, henvises det også til Marco Polo II og Den europeiske investeringsbank som potensielle europeiske finansieringskilder.

\subsection{Norge}

\section{NOx-fondet}

I Norge har 15 næringsorganisasjoner i 2008 opprettet et fond, som har som formål å redusere NOx-utslipp. Foretak som er avgiftspliktige og som slutter seg til fondet slipper for å betale NOx avgift til staten, men betaler samme beløp til fondet. Alle midler som fondet mottar, anvendes til å redusere NOxutslipp. Fondets virksomhet er vurdert av EU, og bedømmes ikke å være konkurranseforvridende ${ }^{17}$.

Fondet har kapasitet til å utdele ca. 80 MEuro årlig til investeringer til skip som seiler i norske farvann og industrianlegg på land til noen av de ca. 650 bedrifter som er medlemmer. I dag utgjør bevilgninger til omstilling til LNG ca. halvdelen av alle utdelinger, og det er over 50 LNG skip som har mottatt støtte.

\section{Fondet kan bl.a. støtte:}

- Nybygg som skal drives på gass og ombygging til gassdrift

- LNG-infrastruktur

- Nye og lovende NOx-reduserende tiltak

- SCR-anlegg med bruk av urea på skip

- SCR- og SNCR-anlegg i avfallsforbrenningsindustrien

- Elektrisk drift av ferger og andre passasjerskip

- Gass i industrien

- Lav-NOx motorombygging

- Motorbytte

I de fleste tilfelle kan fondet finansiere inntil $80 \%$ av investeringskostnadene hvis de oppfyller kriterier om utslipp. Fondet har bidratt til en årlig reduksjon av NOx-utslipp som tilsvarer 19.000 tonn, og det forventes at det i 2017 vil være kommet 16.000 tonn i tillegg 18 .

\footnotetext{
${ }^{16}$ Commission Staff Working Paper, "Pollutant Emission Reduction from Maritime Transport and the Sustainable Waterborne Transport Toolbox", Brussel 16.9.2011.

${ }^{17}$ Støtte gis til tiltak som gir reduksjoner utover lovfestete krav. Dette er knyttet opp mot statsstøtteregler, som angir at en ikke kan motta støtte for å tilfredsstille eksisterende krav. Virksomhet som opererer under maritimt regelverk vil ikke kunne motta støtte fra NOx-fondet etter et eventuelt Tier III krav har trådt i kraft All annen virksomhet som ikke berøres av et Tier III krav vil fortsatt kunne motta støtte fra NOX-fondet. Tier III er en politisk fastsat grænse for, hvor meget en ikke-vejgående dieselmotor må forurene. Tier betyder "gradvis" og beskriver, hvorledes normerne skærpes i rater. Nummeret angiver, at vi er nået til Tier-kravets tredje udgave.

18 Kilde: Control mechanisms for Nordic ship emissions, TemaNord 2013:518 og Nox fondest hjemmeside www.nho.no
} 


\section{Støtte til LNG-terminaler}

Enova, som eies av olje- og energidepartementet, har 30 millioner kroner å bruke i året til støtte for infrastrukturutbygging for naturgass. Dette er en egen post på statsbudsjettet og holdes utenom Enovas energifond.

Efter ansökan har Enova under våren 2013 beslutat att stå för 25 \% av investeringskostnaden för Gasnors etablering av en LNG-anläggning i närheten av Sarpsborg i Östfold. Tanken är att Gasnors anläggning inom några få år ska kunna försörja industrin på Östlandet och delar av Väst-Sverige med LNG. Det finns ytterligare LNG-terminaler i Norge, såväl utanför Stavanger som utanför Fredrikstad.

\subsection{Finland}

\section{Støtte til investeringen i fartøy ${ }^{19}$}

Finske rederier kan søke til investeringsprosjekter, som medfører betydelig forbedring av miljøet. Fra april i år gjelder ordningen også for skip som allerede er i bruk. Ordningen er rettet mot investeringer i teknologier som renser utslipp, og spesielt for å redusere utslipp av svovel. Det kan være tale om investeringer for å gjøre det mulig å skifte til annet og renere brensel eller for å rense utslipp. EU har godkjent støtteordningen hvis den høyest utgjør $50 \%$ av investeringskostnadene. I statens budsjett i 2013 er det bevilget 30 millioner Euro til støtten.

\section{Støtte til LNG-terminaler ${ }^{20}$}

Den finske stat har bevilget 100 millioner Euro til investeringer i LNGterminaler i 2013 og 2014. Regler for støtten er vedtatt i Finland, men er for tiden til behandling i EU- Kommisjonen for å sikre at de er i overenstemmelse med EUs regler om statsstøtte. Reglene ventes å tre i kraft i september. Ordningen er utviklet som et energitiltak ${ }^{21}$.

\subsection{Sverige}

\section{Farledsavgift}

Siden 2004 har den svenske sjøfartsmyndigheten pålagt differensiert farledsavgift på skip. Intensjonen er å skape økonomiske insitament for å redusere fartøyenes negative miljøpåvirkning. Fartøy som anvender drivstoff med sovelinnehold under $0,5 \%$ får en betydelig reduksjon i avgiften, og hvis innholdet er under 0,2\% er skipet fritatt fra å betale avgiften. Skip som har

\footnotetext{
19 Kilde: $\underline{\text { http://www.lvm.fi/web/sv/pressmeddelande/-/view/4142520 }}$

20 Kilde: http://www.tem.fi/index.phtml?l=sv\&s=5353

21 Investeringer av denne typen er underlagt EUs regler for nasjonal regional støtte 2007-2013 (OJC54, 4.3.206)
} 
utstyr til å redusere utslipp av NOx får også lavere farledsavgift på skala fra $10 \mathrm{~g} / \mathrm{kWh}$ til 0,4 g / kWh hvor skipet er avgiftsfritt.

\section{Stöd till LNG-terminal}

I mars 2013 godkände Sveriges regering en ansökan om EU-medel till att etablera en LNG-terminal i Göteborgs hamn. Målet är att terminalen ska vara operativ från och med 2015. Tanken är att LNG-terminalen ska kunna servicera såväl sjöfarten som industrin i Väst-Sverige. Bakom satsningen står bl.a. Swedegas, samt hamnarna i Göteborg och Rotterdam, som i partnerskap satsar på att etablera LNG som framtidens drivmedel inom sjöfarten.

\subsection{Danmark}

\section{Partnerskap}

Det finnes ikke noen spesielle støtteordninger i sjøfarten i Danmark, som er rettet mot å redusere utslipp av svovel eller $\mathrm{NOx}^{22}$, men det er opprettet et Partnerskap for Renere Skibsfart ${ }^{23}$ av Miljøstyrelsen og Danmarks Rederforening, som bl.a. har som formål å redusere utslipp fra skipstrafikken. Partnerskapet arbeider i henhold til en arbeidsplan, som identifiserer et antall mulige tiltak hvorav de fleste tar sikte på å utvikle og prøve tekniske løsninger.

\section{Stöd till LNG}

Danska sjöfartsmyndigheter har inlett en dialog med lokala och regionala intressenter i syfte att etablera konkreta LNG-demonstrationsprojekt. Man har även igångsatt ett projekt kring en harmoniserad tillgång till utvecklingen av tankningsstationer för LNG i Östersjöregionen, närmare bestämt i 9 hamnar runt Östersjön, där bland annat Malmö-Copenhagen Port, samt hamnen i Århus ingår.

\section{Kontroll}

For å sikre gjennomføringen av de nye krav, og at alle rederier er underlagt samme konkurranseforhold, er det i Danmark utviklet et system med automatiske måleapparater, som kan identifisere skip som ikke oppfyller regler om utslipp.

\section{$5.6 \varnothing$ vrige Østersjøland}

Informasjon om planlagte eller gjennomførte tiltak eller støtte-ordninger i de øvrige Østersjøland er ikke lett tilgjengelig. Det kan konstateres at Estland ikke har innført tiltak. I Tyskland er det tilgang til lånefinansiering med

\footnotetext{
22 Kilde: Reducing Air Pollution from Ships, Danish Ministry of the Environment, 2012 ${ }^{23}$ http://www.ecoinnovation.dk/Emneoversigt/Partnerskaber miliøteknologi/Partnerskabet for renere ski bsfart/Ambitioes handlingsplan.htm
} 
subsidierte renter og støtte til å utvikle rensningsanlegg på skip ${ }^{24}$. Det förefaller som om länder som Lettland och Polen är bekymrade över konsekvenserna av införandet av svaveldirektivet, men att man har vaknat upp för sent för att hinna vidta några nämnvärda åtgärder.

\section{Konklusjoner og anbefalinger om felles nordiske tiltak}

Nye krav om utslipp av svovel er uunngåelige og ønskelig på grunn av gunstige miljø- og helbredseffekter. De nye krav ventes også at fremme teknologisk utvikling. De er også i linje med et grunnleggende miljøpolitisk prinsipp, at forurenseren skal betale for sin miljøpåvirkning eller tiltak for å begrense den. Det er en utfordring for områdets konkurranseevne at det vil gjelde lempeligere regler om svovelutslipp for det meste av verden i forhold til Østersjøen, Kattegat og Nordsjøen. Sjøtransport er fra et miljøperspektiv et positivt alternativ til transport på veier. Overføring av transport fra sjø til veitransport på land bør derfor unngås.

Det er forskjeller i vurderingen av hvor vanskelig det vil bli å oppfylle de nye krav om utslipp i de berørte nordiske land. I Norge og Danmark er vurderingen at det vil være mulig å oppfylle de nye utslippsregler uten større konsekvenser for transport- og eksportsektorene ${ }^{25}$. I Sverige og Finland, er det en utbredt bekymring for at transportkostnadene vil øke betydelig, og at det vil ha meget alvorlige konsekvenser for konkurransesituasjonen, spesielt for malm- og skogsindustriene samt gruvedriften, som er lokalisert i de nordlige delene av disse landene. Disse sektorer eksporterer størstedelen av sin produksjon, transport er en vesentlig utgiftspost, og de er underlagt globale markedspriser. På sikt vil utbygning av jernbane kunne løse transportbehovet, men innen da vil de nye regler kunne ha alvorlige konsekvenser for det lokale næringsliv. Det finnes ikke tiltak eller planer om tiltak som er øremerket til å lette tilpasningen på kort sikt for meget utsatte sektorer og geografiske områder ${ }^{26}$. En konsekvensutredning er en forutsetning for å vurdere mulig tiltak ${ }^{27}$.

\footnotetext{
24 Kilde. Rapporten Konsekvensera av skärpta krav för svavelhalten i marint bränsel - delredovisning, rapport 2013:7. Trafikkanalyse samt kontakt med relevante instanser i Estland og Tyskland. ${ }^{25}$ Norges Rederiforbund har i en uttalelse konstatert at det ikke kan støtte reversering av EU-direktivet da dette kan virke konkurransevridende for de rederier som allerede forholder seg til regelverket, og at det vil kunne undergrave IMOs autoritet og posisjon som lovgivende organ innenfor det maritime politikkområde. 26 I en rapport fra Sjøfartstyrelsen i Sverige fra 2009 med en oversikt over mulige virkemidler, inklusive subsidier til definerte havner (i Bottenviken), investeringsstøtte, redusert farselsavgift, avgiftsfri strømforsyning til skip. 
På Åland er sjøfarten i seg selv en stor andel av BNP og alle endringer i sjøfartens konkurranseforhold vurderes fra dette perspektiv.

Det vil være forbud mot statlige støtteordninger fra 1. januar 2015. Derfor skal det ageres hurtig, hvis de nordiske lands regjeringer vil lette overgangen med støttende tiltak. Finland har opprettet en støtteordning med midler fra staten i 2013 og 2014. Norge har et NOx-fond som letter tilpasningen og er finansiert av sektoren og betegnes derfor ikke som statsstøtte.

EU har flere ordninger som kan bidra til å finansiere omstillingen. Resultatet av pågående forhandlinger om partnerskapsavtaler om midler fra EUs strukturfond vil ha innvirkning på muligheten for å søke finansiering til relevant infrastruktur i Danmark, Sverige og Finland i perioden 2014 til 2020.

Markedet kommer til å tilpasse seg de nye regler. Ikke alle bedrifter kan reddes i transformasjonen, og det ventes samfunnsøkonomiske konsekvenser av transformasjonen; dårligere konkurranseevne og tap av arbeidsplasser.

Fraktskip har en levetid på ca. 25 år. Ved bygging av nye skip kan det legges til rette for å oppfylle nye krav om svovelutslipp uten betydelige merkostnader. Problemet er den store flåte av skip som ble bygget og er i drift med utgangspunkt i de eldre og mer lempelige regler. Det er behov for å skape en klarhet om hvor omfattende behovet er for å fornye eller ombygge fraktskipflåten, som fra 2015 skal sørge for sjøtransporten i Østersjøen, og hvilke konsekvenser de nye reglene vil få for disse eldre skipene og dermed størsteparten av skipsfarten.

Det finnes flere tekniske alternativer for rederiene å velge i mellom: dieselolje og andre typer av renere brensel, LNG, rensing av utslipp, dobbel brensel-system og lavere fart. Det er fornuftig ikke å låse seg fast på en enkelt løsning. Gruppen vurderer dog at LNG (flytende naturgass) og metanol ${ }^{28}$ sannsynligvis vil være fremtidens viktigste brensel i skipstrafikken i Østersjøen. Videre, at marindiesel vil bli brukt i en overgangsfase. Regelverket for bruk av LNG er mangelfullt eller ikke eksisterende og her er det behov for en hurtig innsats fra det offentlige. Et arbeid med at utvikle ett felles syn/regelverk vedrørende håndteringen av LNG er kommet i gang ${ }^{29}$ men

være relativt liten, men store lokale og regionale konsekvenser kan ikke utelukkes. I sluttrapporten vil dette bli belyst.

${ }^{28}$ Flammepunkt for metanol er 12 grader $\mathrm{C}$ og derfor er bruk av det med dagens teknologi forbundet med større risiko en marindiesel.

${ }^{29}$ Se for eksempel rapporten "North European LNG Infrastructure Project, Summary Report» Danish Maritime Authority, mai 2012 
det vil ta tid at gjøre det klart. Det mangler også en felles strategi for utbygging av en dekkende LNG-infrastruktur i Norden og Østersjøområdet. Sterk politisk oppbakking er en forutsetning for hurtig implementering og fremgang i disse tingene. Det er en oppgave som bør prioriteres i de nordiske land.

Begrenset tilbud av diesel og høye priser vil kunne bli en utfordring for rederiene i overgangsfasen. De høyere dieselpriser vil også påvirke veitransporten. At regler om flammepunkt er forskjellige for marindiesel og alminnelig diesel er et uheldig og unødvendig hinder ifølge et forslag som USA presenterte i IMO i $2013^{30}$.

De nye og strenger regler for svovel, samt NOx, har skapt, og ventes å skape ytterligere nye muligheter for den delen av industrien som kan levere de nye løsninger. Utsettelse av implementeringen av NOx-reglene, som drøftes i IMO ${ }^{31}$, kan ha negativ innvirkning på dette.

For å sikre fair konkurranse etter at de nye regler er implementert er det viktig å stoppe fusk. Det krever overvåkning fra myndighetenes side. Danmark har planer om å sette opp instrumenter («sniffers») som måler svovelutslipp i passerende skip.

Det er meget positive erfaringer med det norske NOx-fond som ble etablert av næringslivet i 2008 og finansieres med avgifter fra næringslivet. Fondet finansierer tiltak til å redusere utslipp og letter dermed tilpasningen til de nye svovel og NOx-regler. Erfaringene med NOx-fondet viser at miljøavgifter i større grad med fordel bør kanaliseres til å finansiere løsninger på de selvsamme miljø-problemer, og i mindre grad anvendes som en inntektskilde for staten. Gruppen anser, at på kort sikt kan NOx-fondmodellen ikke brukes av de andre nordiske land, men erfaringen viser at økonomiske insitamenter letter overgangen til renere teknologier i sjøfarten, og NOx-fondet kan de øvrige nordiske land med fordel bruke som inspirasjon til å skape egne insitament-modeller.

Det er en reell risiko at varetransport flyttes fra sjøtransport til transport på landeveier. Det vil skape ytterligere trengselsproblemer og miljøbelastning. I den forbindelse observeres at i EUs hvitbok om transport, er målet at ingen transport av varer som overstiger $300 \mathrm{~km}$ skal foregå på veiene. Ytterligere

\footnotetext{
${ }^{30}$ International Maritime Organisation (IMO), Maritime Safety Committee's 92nd session, agenda item 10, Comments on document MSC 92/10 submitted by the United States.

31 Det har vært forslag i arbeidsgrupper i IMO at forsinke implementering av de regulerende tiltak. Det har skapt usikkerhet for produsenter av de nye teknologier som skal erstatte de eldre mer forurensende teknologier.
} 
avgifter på veitransport, vurderer Gruppen ikke som et politisk alternativ, bl.a. fordi det i mange tilfeller ikke er noe alternativ til veitransport, som for eksempel i Nord-Finland. En senkning av havne- og/eller farleds- avgifter vil kunne bidra til å styrke sjøtransportens konkurranseposisjon i forhold til veitransport.

I lys av ovenstående anbefaler arbeidsgruppen at Næringsutvalget og Miljøog naturressursutvalget framlegger et utvalgsforslag til behandling på Nordisk råds sesjon i Oslo i oktober 2013 som inneholder følgende rekommandasjoner:

a) at de nordiske lands regjeringer implementer tiltak for å opprettholde og styrke sjøfartens konkurransekraft

b) at de nordiske lands regjeringer samarbeider om å utvikle felles reguleringer for bruk av LNG i Norden og internasjonalt, og at de nordiske regjeringer utarbeider nasjonale planer for opprettelse av LNG terminaler i nordiske havner.

c) at Danmark, Finland og Sverige inkluderer finansiering av infrastruktur for sjøtransport, inklusive LNG-terminaler, i partnerskapsavtaler om midler fra EUs strukturfond i perioden 2014 til 2020

d) at de nordiske lands regjeringer arbeider for at samme regler gjelder for flammepunkt for marin diesel som for alminnelig diesel

e) at de nordiske lands regjeringer innenfor EU, IMO og andre relevante internasjonale fora, arbeider for at samme regler som gjelder for utslipp av svovel i Østersjøen, Kattegat og Nordsjøen, samt Nord-Amerikas kyst, også tidligst mulig gjelder for andre havområder

f) at regjeringen i Norge, Sverige og Finland, samordner og prioriterer gjennomføringen av planer om å styrke og utvide jernbanekapasiteten i de nordlige områder, samt forbindelse til havner i Norden utenfor SECA-området, som til eksempel Narvik og Trondheim

g) at regjeringene i Sverige og Finland undersøker konsekvensene av implementeringen av svoveldirektivet på særlig utsatte sektorer i avgrensede geografiske områder, samt om det i en overgangsperiode er mulig å innføre spesielle regionalbaserte tiltak for å unngå den negative innvirkning implementeringen av svoveldirektivet vil ha på lokal og regional økonomi. 
h) at de nordiske lands regjeringer skaper økonomiske insitament for bruk av renere teknologier i sjøfarten, som bygger på erfaringene med det norske NOx-fondet.

i) at de nordiske lands regjeringer kartlegger den eksisterende skipsflåte som betjener landene, for å belyse omfanget av den omstillingen som implementeringen av svoveldirektivet forutsetter 


\section{Bilag}

På Näringsutskottets och Miljö- och naturresursutskottets gemensamma möte i Reykjavik den 29 januari 2013, beslutades att respektive lands delegation, med undantag av Island, Färöarna och Grönland, skulle utse en representant till en ny arbetsgrupp som skulle arbeta med problemställningar kopplade till implementeringen av EU:s Svaveldirektiv

\section{Gruppens sammansättning}

Arbetsgruppen har bestått av följande personer: Oskar Grimstad (Norge), Anders Eriksson (Åland), Eero Suutari (Finland). Thomas Danielsen (Danmark) och Billy Gustafsson (Sverige). Oskar Grimstad har varit gruppens ordförande och Anders Eriksson vice ordförande. Tryggvi Felixson och Johan Lindblad från Nordiska rådets sekretariat i Köpenhamn, har fungerat som sekretariat åt gruppen. De enskilda representanterna har i tillägg haft nationella tjänstemän som bisittare under mötena.

\section{Gruppens uppdrag}

Gruppen fick på mötet i januari 2013 nedanstående uppdrag:

Å vurdere mulige felles nordiske tiltak for å lette implementeringen av svoveldirektivet for sjøfarten i Østersjøen, Kattegat og Nordsjøen, og om eventuelt felles innspill fra Nordisk råds side.

Arbeidsgruppens oppdrag er å skape klarhet om mulig testperioder for nye teknologier eller andre former for overgangsordninger ved innføringen av svoveldirektivet i 2015. Videre å kartlegge og sammenlikne eksisterende støtteordninger til omstilling til nye teknologier som reduserer svovel og NOx utslipp fra skip, både i de enkelte nordiske land og EU, som rederiene kan benytte seg av.

Arbeidsgruppen skal vurdere mulig felles nordiske tiltak for å lette implementering av svoveldirektivet for sjøfarten i Østersjøen, Kattegat og Nordsjøen, og utarbeide forslag til innspill fra Nordisk råds side herom.

På arbetsgruppens möte i Mariehamn den 24/6 2013, konstaterades att frågan om möjliga testperioder, som en del av uppdraget, inte var möjliga, vilket man lyfte fram och fick accept för i en särskild delrapport till de båda utskotten.

\section{Gruppens möten och aktiviteter}

Gruppens konstituerande och första möte ägde rum i Stockholm den 10/4. För att få en grundlig genomgång och presentation av den samlade problematiken, hade gruppen inbjudit Per-Åke Hultstedt, som är projektledare på Länsstyrelsen i Västernorrland, och som har lett ett projekt och skrivit en 
rapport om Svaveldirektivet, där problematiken framför allt belyses utifrån ett nordsvenskt och delvis nordfinskt perspektiv. På detta möte beslutade arbetsgruppen också om gruppens arbetsplan, där man i princip beslutade att hålla ytterligare tre möten och att i samband med respektive möte särskilt belysa situationen i utvalda länder i Norden och närområdet. Det första mötet fokuserade således särskilt på svenska regler och förhållanden.

Gruppens andra möte hölls som videomöte den 23 maj. Til møtet hadde sekretariatet utarbeidet et notat om nasjonale støtteordninger og EUs støtteordning. Länderna gicks igenom och beskrevs kort. Til møtet hadde sekretariatet også utarbeidet ett underlag om de tekniske løsninger som rederiene kan anvende for å leve opp til de nye krav om utslipp av svovel. Man diskuterade också problematiken kring konkurrensen mellan vägtransporter och sjötransporter och risken för att fler transporter övergår till landsväg.

Gruppens tredje möte ägde rum i Mariehamn den 24 juni. Till mötet hade gruppen inbjudit representanter för Finlands rederiförbund för att få dess syn på problematiken, Viking Lines tekniska direktör, för att få veta mer om LNG (Liquid Natural Gas) som tänkbart framtida drivmedel, samt BSPCs maritima rapportör, för att höra närmare om hur man har arbetat med frågan inom BSPC. Vidare diskuterades villkoren för vägtrafik samt potentialen att överföra fler framtida transporter från sjöfart till räls, samt vilka stödjande åtgärder som andra länder runt Östersjön vidtagit för att hjälpa sina företag och rederier i övergången till 2015. På mötet i Mariehamn diskuterades även det första utkastet till rapport från svavelgruppen, till de båda utskotten.

Gruppens fjärde möte ägde rum i Köpenhamn den 28 augusti, och hade fokus på danska och norska förhållanden. Särskilt inbjudna var Dansk Maritime (dansk branch- och arbetsgivarförening för danska leverantörer av maritim utrustning och skepp) och Fjord1 (Norskt färjebolag). Genom input från de externa presentatörerna bekräftades den bild av problematik och tänkbara insatser som Gruppen fått under arbetets gång. Vid mötet genomgicks utkastet till slutrapport från arbetsgruppen, till de både utskotten på nytt, med för slag till insatser som utskotten kan ställa till Nordiska rådet och rådet därefter till de nordiska regeringarna. Avklarande möten i arbetsgruppen hålls endast om nödvändigt.

I och med slutrapporten till de båda utskotten anser sig arbetsgruppen ha slutfört sitt uppdrag.

Samtliga möten har tolkats mellan Skandinaviska och finska, men det skrivna materialet har som regel inte översatts till finska. 


\section{Referencer}

- Arbets- och näringsministeriet. 2013. Investeringsstöd för LNGterminaler.

http://www.tem.fi/index.phtml?l=sv\&s=5353

- Danish Maritime Authority. 2012. North European LNG Infrastructure Project. Summary Report.

- Danske Maritime. 28 augusti 2013. Föredrag på arbetsgruppens möte i Köpenhamn.

- Estland. E-mail fra Silver Vahtra, Counsellor Marine Environment Dept.Estonian Ministry of the Environment

- European Commission. 2011. Commission Staff Working Paper: Pollutant Emission Reduction from Maritime Transport and the Sustainable Waterborne Transport Toolbox. Brussels: European Commission.

- European Commission. Trans-European Transport Network Executive Agency (TEN-T EA). http://tentea.ec.europa.eu/en/home/

- European Commission. 2012. Regional Policy - Inforegio. The Funds: European Development Fund.

http://ec.europa.eu/regional policy/thefunds/regional/index en.cfm

- Helsinki Commission. Emissions from ships. http://www.helcom.fi/shipping/emissions/en GB/emisions/

- International Maritime Organisation (IMO). Maritime Safety Committee's 92nd session. Agenda item 10. Comments on document MSC 92/10 submitted by the United States.

- Jordal-Jørgensen, Jørgen. 2012. Reducing Air Pollution from Ships. A cost benefit analysis and feasibility study on possible means for further reduction of emissions. Rapport/Danish Ministry of the Environment. København: Miljøstyrelsen.

- Kommunikationsministeriet. Pressmeddelande: Investeringsstöd för fartyg ger lättnader i anpassningen till svavelutsläppsgränserna. 14.03.2013 http://www.lvm.fi/web/sv/pressmeddelande/-/view/4142520 
- Ljungberg, Anders et. al. 2013. Konsekvenser av skärpta krav för svavelhalten I marint bränsel - delredovisning. Rapport/Trafikanalys 2013:7. Stockholm: Trafikanalys.

- Martinsen, Kjetil \& Torvanger, Asbjørn. 2013. Control mechanisms for Nordic ship emissions. Rapport/TemaNord 2013:518. København: Nordic Council of Ministers.

- Miljøministeriet. Ecoinnovation. Ambitiøs handlingsplan for renere skibsfart.

http://www.ecoinnovation.dk/Emneoversigt/Partnerskaber_miljøtekno logi/Partnerskabet for renere skibsfart/Ambitioes handlingsplan.htm

- Miola, Apollonia et. al. 2010. Regulating Air Emissions from Ships. The State of Art on Methodologies, Technologies and Policy Options. Rapport/European Commission. Luxembourg: Publications Office of the European Union.

- Næringslivets Hovedorganisasjon (NHO). www.nho.no

- Norges Rederiforbund. 24 juni 2013. Föredrag på arbetsgruppens möte på Åland.

- Official Journal of the European Union. 2012. Directive 2012/33/EU of the European Parliament and of the Council of 21 November 2012 amending Council Directive 1999/32/EC as regards the sulphur content of marine fuels. http://eurlex.europa.eu/LexUriServ/LexUriServ.do?uri=0J:L:2012:327:0001:0 013:EN:PDF

- Tyskland, e-mail svar fra Holger Steinbock BG Verkehr/BG for Transport and Traffic. Dienststelle Schiffssicherheit/Ship Safety Division

- Söfartsverket Sverige, Konsekvenserne av IMO:s nya regler för svovelhalt i marint bränsle, 2009-05-14 